\title{
TRANSFORMATION FROM TENT TO ROOM: ROOM OF TRADITIONAL TURKISH HOUSE
}

\author{
Deniz Demirarslan \\ Ass.Prof Dr.,Kocaeli University, TURKEY, demirarslandeniz@gmail.com
}

\begin{abstract}
The room has a function of nucleus in the formation of Turkish House which has an important place in the sense of traditional residence features in the world and the planning of this residence begins with room. Therefore, this residence is a phenomenon that develops from inner space through outer space. The formation of the room of traditional Turkish house is influenced by various elements. On top of them there come the requirements of nomads and Turkish-Islamic life style. The effects of these are clearly observed in the architectural design and decoration of the room which is shaped by the features of traditional life and bestows its design characteristics from nomad tent. Before immigrating to Anatolia from 11th century A.D., Turks have lived mostly a nomadic life in Middle Asia. Therefore, just like in other Middle Asia cultures; Turks have lived in temporary shelters. After settling in Anatolia and before that after accepting Islam; Turks have started to lead a sedentary life and formed a new living culture with the effect of various Anatolian civilizations, notably the Byzantines. In this way, a type of residence which is built in Anatolia, Balkans and Caucasus in the period of Ottoman Empire has emerged. The room of this type of house which lasted from 15th century to the second half of 19th century forms the nucleus of design. It is possible to pursue the traces of nomadic period and Turkish-Islamic life style as the characteristics of design in the design of this room.In the scope of this study, characteristics of design of the room which forms the design nucleus of traditional Turkish House is studied and similarities and differences with tent which are the shelters of nomadic period are observed in the sense of usage and function. Safranbolu district which is has around 2000 traditional houses and which is recorded in the list of cultural heritage by UNESCO is chosen. Safranbolu is an important settlement which is on the old Silk Road in Anatolia and developed in the period of Ottoman Empire. Through the end of 18th century famous geographer Ibn Sa'id asserted that 100.000 nomads with tents were living in the area in which Safranbolu is also included. Therefore, an important historical characteristic of Safranbolu area is the settlement of nomadic people called "Yoruk" who carried the nomadic living tradition of Middle Asia to Anatolia and reflecting their way of living on their houses. In this sense, Yoruks have great effect on the historical development of the area. Safranbolu houses are chosen for the reasons that they have all the features of a traditional residence; reflect the geographical, economic and social structure of the area on the houses at best and have rich examples in the sense of room design. For this reason, first of all general features of life style in the nomadic period and in the period before the acceptance of Islam and then the effects of these features on the spaces of shelter were studied. In the second process, shelter spaces of nomadic period were observed, in the third process general features of traditional Turkish house were studied, in the fourth process the formation of room in this residence types was studied in the sample of Safranbolu house and finally expressing the similarities and differences between nomadic period shelters and room, elements that influence the formation of room and the results were studied in the light of findings.
\end{abstract}

Keywords: Traditional architecture, Turkish room, tent. 


\section{INTRODUCTION}

History of civilization is based on the transfer of cultural heritage which is invigorated especially by architecture among generations. Inner space of the residence and the belongings we use in daily life are the important components of this cultural heritage. With the description of Chinese philosopher Lao Tzu "the reality of the building does not consist in the roof and walls, but in the space within to be lived in"; it is expressed that architecture, inner space and belongings are the mirror of cultural identity of communities (Nute, 2000, p.123). Famous architectural historian and theoretician Norberg-Schulz defines architectural products as the manifestation of socio-cultural features being a cultural identity (Norberg- Schulz, 1965, p.156). According to the definition of Rapoport who is known for his studies about residences, residence which is an architectural product is formal organization and a cultural phenomenon (Rapoport, 1982). The residence is shaped and privatized by the needs and actions of the people living within. The space of residence is explained by the equipments and decorations which is present in it and shaped by the life culture (Gur, 2002, p.164).

Traditional Turkish house is shaped by the needs, traditions, customs and activities of the people living within. In the development of this type of residence there are various views of experts who have made researchers upon this subject. In the formation of this type of residence; nomadic life style of Turkish people which is brought from Middle Asia is effective according to Kucukerman (1973, p.5) and Tanyeli (1978, p. $30)$; and according to Kuban(2007, p.469) living habits after the acceptance of Islam is effective. Aksoy (1963, p.39) asserted that Turkish house has been developed primarily by climate, geographical conditions and structure material and then with the effect of nomadic Turks and Anatolian civilizations. Before immigrating to Anatolia from $11^{\text {th }}$ century A.D., Turks have lived mostly a nomadic life in Middle Asia. Therefore, just like in other Middle Asia cultures; Turks have lived in temporary shelters. After settling in Anatolia and before that after accepting Islam; Turks have started to lead a sedentary life and formed a new living culture with the effect of various Anatolian civilizations, notably the Byzantines. In this way, a type of residence which is built in Anatolia, Balkans and Caucasus in the period of Ottoman Empire has emerged (Eldem,1984, p.13). In fact, record of this residence type in the literature history of architecture after being observed by Western architects coincides with $18^{\text {th }}$ century. In 1740, Jean Etienne Liotard published a book in which there are drawings about a Turkish house. Moreover, in 1819 Antoine Melling published a book on the same subject and similar publishing were done in the $19^{\text {th }}$ century. In the $20^{\text {th }}$ century Le Corbusier studied old Turkish houses in Istanbul in the sense of geometry, aesthetics and material usage and published his rough copies in a book (Yurekli \& Yurekli, 2005,p.85). However, the person who first grouped and named this traditional house type topologically in the $20^{\text {th }}$ century is the famous Turkish architecture Sedad Hakkı Eldem. The room of this type of house which lasted from $15^{\text {th }}$ century to the second half of $19^{\text {th }}$ century forms the nucleus of design. It is possible to pursue the traces of nomadic period and Turkish-Islamic life style as the characteristics of design in the design of this room.

\subsection{Scope And Method Of The Research}

In the scope of this study, characteristics of design of the room which forms the design nucleus of traditional Turkish House is studied and similarities and differences with tent which are the shelters of nomadic period are observed in the sense of usage and function. Safranbolu district which is has around 2000 traditional houses and which is recorded in the list of cultural heritage by UNESCO is chosen. Safranbolu is an important settlement which is on the old Silk Road in Anatolia and developed in the period of Ottoman Empire. Moreover, in the periods before Turks settled in Anatolia after the Victory of Malazgirt, some of the nomadic Turkish races came and settled here leading a nomadic life for a long time. Through the end of $18^{\text {th }}$ century famous geographer Ibn Sa'id asserted that 100.000 nomads with tents were living in the area in which Safranbolu is also included (Şahin, 2003, p.7). Therefore, an important historical characteristic of Safranbolu area is the settlement of nomadic people called "Yoruk" who carried the nomadic living tradition of Middle Asia to Anatolia and reflecting their way of living on their houses. In this sense, Yoruks have great effect on the historical development of the area. Safranbolu houses are chosen for the reasons that they have all the features of a traditional residence; reflect the geographical, economic and social structure of the area on the houses at best and have rich examples in the sense of room design. For this reason, first of all general features of life style in the nomadic period and in the period before the acceptance of Islam and then the effects of these features on the spaces of shelter were studied. In the second process, shelter spaces of nomadic period were observed, in the third process general features of traditional Turkish house were studied, in the fourth process the formation of room in this residence types was studied in the sample of Sarfanbolu house and finally expressing the similarities and differences between nomadic period shelters and room, elements that influence the formation of room and the results were studied in the light of findings. In the first three phase of the study literature research was done; in the analysis phase the houses of Safranbolu district in which the room design characteristics were observed at best were studied. 


\section{GENERAL FEATURES OF NOMADIC AND TURKISH-ISLAMIC LIFE STYLE and EFFECTS ON SHELTER CONDITIONS}

Oswald Menghin, expressing that nomadic culture was initialized by Ural-Altay races in Asia; named this culture as "Miclitische of Ural-Altay races in Middle Asia are one of the communities who are mostly related with this culture (Larszle, 1981, p.1). After Turks' accepting Islam and then setting in Anatolia, a new living culture that is shaped by nomadic period habits was formed being influenced by various civilizations an Anatolia. Anatolia as an important geographic region especially in Neolithic period hosting important settlement areas such as Çatalhöyük (B.C. 7000) and being home for different civilizations in different periods of the history. This new living culture which was influenced by the architectural richness of Anatolia influenced especially the architecture of residence as the famous archaeologist Josef Stryzgowski asserted (Koprulu, 1974, p.1). As a result, this new living culture which was influenced both by nomadic and TurkishIslamic life culture and by Anatolian civilizations develop some principles based on respect towards nature, modesty, simplicity and spirituality. One of the most important principles of this new living culture is the principle of "earth is below our feet, firmament is above our head." This living principle explains that for a Turk everywhere can be a place of shelter. Another important principle is that "few but the main." This principle means to do much activity with fewer tools, and the need to place these tools easily accessible in the places of shelter. "Functionality in daily life" is another important principle. According to this principle; functionality is essential in the formation of every tools used in daily life and the place in which people live. The same principle is observed in the modern architecture of 20th century as "form follows function."

Since nomadic life and Islam gave importance to spiritual life, "temporality of life" was taken as basis in this living culture. Since people are mortal, the place in which people live was regarded as a temporary formation. For this reason, while the function of being temporary was enabled with tents in the nomadic period; in new living culture it was enabled with the place's being simple and plain in the sense of function, form and equipments. Another principle is "prudence". Nomadic life and Islam aimed being prudent and lavishness was not regarded as good. Functionality, simplicity and plainness are the reflections of prudence on the place. Privacy is also effective in the formation of shelters. It was aimed to form privacy in the sense of people and actions among household, neighbours and outer world. Another important feature of this living culture is the way of "Turkish sitting" brought from nomadic period. According to American anthropologist Gordon Hewes, there are 480 different sitting positions in various cultures and these were developed not according to the anatomical features of societies but their cultures (Sheets- Johnstone, 1994, p.77). Turks who have carried out their actions by sitting every clean place in nature sustained the same sitting style after they passed to sedentary life and carried out their actions at house close to floor on the floor or in the middle of the house. The concept of family is important in this living culture. Big and patriarchal family structure shaped the place of shelter. In a shelter; every immediate family that forms the greater family had a place on their own. The need of expressing the hierarchy in the family and the status in the society shaped the shelter as well. Parallel to the needs and principles of this living culture, entrance of the shelter, area in which daily works were done, living area, storage and heather formed important areas of activity.

\section{CHARACTERISTICS OF NOMADIC TENTS}

In the nomadic period and in the period after settling in Anatolia, Turks mostly lived in temporary shelters called "Yurt" and "Karaçadır (Black Tent)". Due to these shelters they dealt with animal husbandry which requires continuous change of place. While husbandry requires movement in order to search for fresh food, conditions of being a warrior society developed nomadic life. Even after passing to sedentary life, people lived in tents for long years. Upon this subject, French ambassador Marquis De Nointel who served in Ottoman Empire expressed that property ownership in Ottoman belonged to Ottoman Sultans, other people used to live in tents or temporary shelters that resemble to tents (Kuban, 2001, p.14). A Safranbolu region which is the study field has been the area in which the nomads lived for long years. Although both are tents; there are important differences between "Yurt" and "Karacadır". "Karacadır" is a tent with stretch structure and made of felt. In his work La Tente Noire, Carl Gunnar Feilberg expressed that the "Karacadır" is the same as tent which has Indian-European origin and brought with Indian-European races from West Asia in A.D.2000 (Feilberg, 1944). Beams of the tent are made of carnipus, oak or juniper. Upon these carriages; candles, lanterns and ornaments were hanged. "Karacadır" is an element which does not insulate from the physical conditions of nature but completes the life. Usage area of the tent is $35-45 \mathrm{~m} 2$ averagely (Fig. 1). Dimensions and the number of tent are detected according to the living status of nomadic families. House holder sits in a specific corner in order to express his status and hierarchy. Outer space which is composed of tents is the common usage area of the families. Yoruk tents and tribe tents in Eastern Anatolia are such kind of shelters in Turkey. As Ozkan (1974, p.22) expressed in his essay, the floor of Karacadır is soil but the sitting is matting. Upon the matting, felt is covered in order to prevent moisture. By placing cushions and 
pillows on felt sitting places are formed. In the direction of wind of the tent storage sacks are placed. In this way; cold air is also prevented to enter in the tent. In some of the tents sacks are placed as to divide the tent into two. In this way; two separate places to sleep are enabled in the tent. Hearth is generally placed close to the door. "Yer sofrası" (Dining table on the floor) is placed on the felt in order to have meal (Kademoğlu, 1974, p.29).

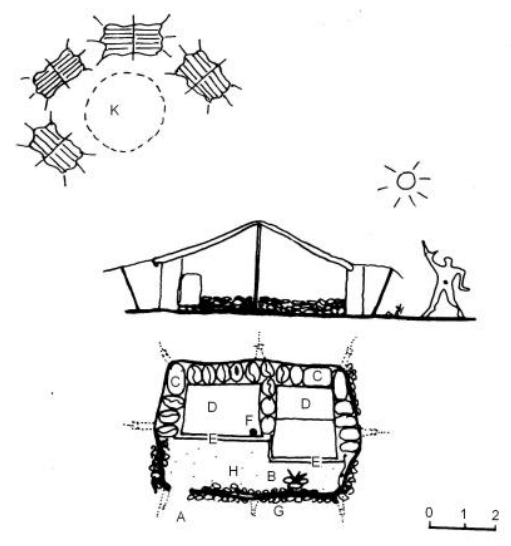

Figure 1. Planning scheme and place usage of Karaçadır. A: Entrance, B: Hearth, C: Storage Sacks, D: Felt laid sitting area, E: Matting Floor, F: Beams, G: Stone Wall, $\mathrm{H}$ : Daily activity are on soil floor, K: Common usage area between tents.

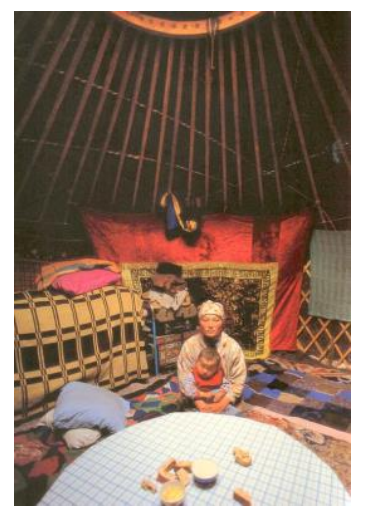

Figure 3: An appearance from the inner space of "Yurt" (Cagatay \& Kuban, 2007, p. 423).

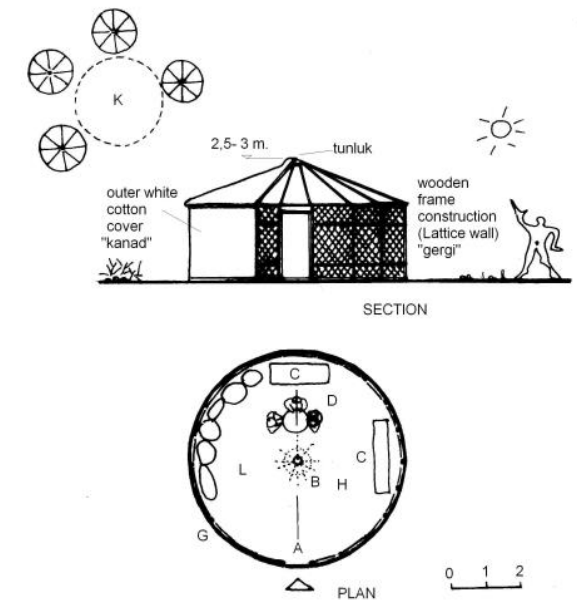

Figure 2. Planning and section scheme of "Yurt" and usage of place. A: Entrance, B: Hearth, C:Storage, D:Sitting, G: Wooden Structure, H: Daily work area-section for women, L:Section for men, $\mathrm{K}$ :Common usage area among tents.



Figure 4: Traditional Turkish House Upper Floor Planning Scheme and Placement of Rooms - Safranbolu Kaymakamlar House.

Moreover, "Yurt" is demounted shelter unit which is observed in Middle Asia since $1^{\text {st }}$ century BC. And used by Turkish races and Mongols. As Ozkan (1974, p.24) asserted in his essay, according to the information obtained from Pazırık Kurganı excavations, the emergence of these tents dates back to Hun Empire. As the famous explorers Marco Polo and William Of Rubruck expressed in their works "Yurt" is in circular form and is a tent formed with juniper. Juniper is used in the structure of this tent because of its flexibility (Wright, 
1958 , p. 159). It is composed of 40 carrier sticks; 20 of them vertical, 20 horizontal. Gaps between the carriers are filled with wooden sticks placed crossed. Carrier sticks are fixed in the soil binding together. Upper corner of the wooden frame is covered with felt. Direction of the door is detected in the direction of wind. Turkish art historian Abdulkadir Inan described "Yurt" as a circular shelter composed of vertical plane and horizontal plane (Arseven, 1955, p.25). The roof of this shelter which has 3-5m diameter and 2,5-3,5 $\mathrm{m}$ height is in the form of dome since it represents the sky according to the religion of Shaman (Fig. 2) (Onuk, 2005, p.23). Nomadic Turks have two different worlds according to the belief of Shaman religion. First of these worlds is their own world of family. This world was a living order composed of tents. Other world belonged to the Gods. This world was believed to be designed above and below the firmament. For this reason firmament was accepted as a tent; and according to the principle "earth is below us and firmament is above our head"; the roof of nomadic tent was shaped as firmament.

Interior order of yurt tent is same everywhere. Tent has specific interior ordering discipline. This discipline enables an opportunity of shelter for a family of $15-20$ people in a circular and narrow space (Onuk, 2005,p.23). The hearth which is placed in the middle of "Yurt" makes a symbolic distinction between the lives of women and men. In some regions of Anatolia hearth is on the left of the entrance. Daily works are carried out by women. The section of men expresses status and hierarchy. Guests are welcomed in this section. A hole, which is the in the middle of dome and named as "kunluk", serves as both chimney and window. All the activities such as cooking, eating, sitting, sleeping, storage were carried out in this shelter with simple and few belongings. Carpet, weavings and cushions are important belongings (Çagatay \& Kuban, 2007, p.405). Richness of patterns and colours of the weavings used in interior space shows the status of the user in the society (Fig.3). Yurt is shaped according to the natural conditions of Middle Asia, optimum shelter conditions were formed against hurricane, cold and hot. It does not conduct cold in winter and hot in summer. Rich families use tents by connecting some of them. This tent is called as "Alaçık" or "Topakev" in some of the regions of Anatolia and used in Turkistan, Uzbekistan, Kirghizstan, Mongolistan, and Azarbaijan. That "Yurt" influenced the formation of architectural structures was asserted by many researchers. Vaults which are important grave structures of Turkish architecture derive from this tent structure according to the assumption of Josef Strzygowski (Esin, 1981, p.166). Moreover in the periods of Seljuk and Ottoman; rooms in the shape of tents were done in which the hearth is replaced in the middle of the place (Kuban, 2001, p.45). Being influenced by the shape and usage of tents; a type of planning called "Asian central planning tradition" emerged in Turkish civil architecture. This type of planning was especially used in Ottoman Palaces; in the design of sultan mansion and medrassah (Arseven, 1955, p.25). Because when the Ottoman Empire gained power politically and economically, tent became the symbol of richness and power (Eldem, 1973, p.373). This type of plan was observed in Çinili Mansion and Istanbul Çadır Mansion in Topkapı Palace (Ozguven, 1996, p.16). Moreover, that the formation of Rumelihisarı and Yedikule were influenced was recorded in various sources (Cagatay \& Kuban, 2007, p. 423). Turkish tents have effect on western architecture as well. Especially the movement of Orientalism which became widespread in $17^{\text {th }}$ and $18^{\text {th }}$ centuries caused the fashion turqueri to emerge in Europe. In the decoration of rooms in which Turkish style ceremonies and feasts were carried out, cushions, divans and Ottoman carpets were used; Turkish motives were included in the architectural and daily belongings. Places for drinking coffee that is designed in Turkish style became popular for European countries. Dome of Belvedere Palace built by architect J.L. von Hildebrandt in Vienna is an example of Turkish inspiration in European architecture. Turkish tent had also influenced garden organizations in Europe. Garden structures in the form of tent used for various aims were built in Sweden, England and Paris. Observation of Turkish house Le Corbusier and modular measurement system that he developed are the results of traditional Turkish houses integration with west. "Turkish Villa" and "Villa Schwab" which was built by Le Corbusier in Switzerland were designed by being inspired by traditional Turkish house in the sense of plan order and interior place feature.

In his works, famous Turkish explorer Evliya Çelebi expressed that there are nomads in the $17^{\text {th }}$ century Western Anatolia who use "Yurt" but the usage of it has decreased in the following periods (Goker, 2009, p.163). Turks, who passed from nomadic life to sedentary life, transformed tents to houses. Formation of these tents and living habits in it has become the design element of traditional Turkish house and tent have transformed into room in this house type. This transformation emerged as single room in the beginning. These first house samples were built totally on soil in the most primitive application periods. For this reason, while passing to sedentary life on soil simple ways of isolating soil were searched. On order to prevent connection with wet floor in the rainy periods in other words in order to enable isolation, the floor of soil was covered with a material such as rug, felt etc. In these applications which have an intermediately structure in transformation from tent to single room house, all the functions (hearth, eating place, sleeping place, closets, press etc.) were replaced in single place. From the development of these single room houses traditional Turkish house emerged (Giray, 2002, p.8). 


\section{GENERAL VIEW ON TRADITIONAL TURKISH HOUSE AND HOUSE OF SAFRANBOLU REGION}

Turks and communities such as Greeks, Armenians who have sedentary life in Anatolia formed famous house model which makes use of belongings that are shaped with their own culture, tradition and needs due to leading sedentary life in Ottoman Empire. This house which is the product of Turkish-Ottoman culture is called as traditional Turkish house and has common architectural qualities which spread to a wide area. This house is certainly a very colourful structure. For this reason, these houses represent the temporary character of Ottoman civilization which reflects nomadic life, Turkish-Islamic life style and the nature of eastern culture. In the formation of Turkish house, apart from the new living culture that is formed of synthesis of nomadic and Turkish-Islamic life style, function and flexibility have been effective. Turkish house is a place that lives just like tent. It was thought as a living organism. House would be born and die. This feature detects the planning, structure and interior place formation of Turkish house. For this reason wooden based material was mostly used in the establishment of Safranbolu house. Ground floor of the house is masonry but the top floor is of wooden frame similar to that in "yurt" tent. In the building techniques of houses, Byzantine, Armenian and Caucasian building techniques draw attention. Rationality is dominant is planning. In the sense building, usage and perception the house was built with a minimalist approach. Top floor of the house which was built with different materials according to the climate and topographic features of the geographical region and which was generally duplex is the primary living floor in the sense of privacy. Planning of this floor begins with the room. Rooms are connected to each other with a living space called "sofa". The most important feature of sofa is apart from forming the circulation among rooms, to be the place where the big family gathers and does daily works. The position of the sofa which is closed, semi-closed and open according to the climate conditions and the relationship of rooms form the plan typology in these houses (Fig. 4). Therefore, traditional Turkish house has developed from the inner space to outer just like in tent.

In Safranbolu district; Turkish-Islamic life style, multi populated patriarchal family structure, climate, regional materials and workmanship, cultural and material wealth are the elements that detect the size and form of the houses. These houses were designed in the frame of happiness in human life regarding the relationship of nature - street - house (Rheidt, 1996, p.20). Houses form traditional Turkish city pattern in a way which do not shadow the daylight of other. In the building of houses; easily found materials, limestone, "kufunk" stone (a porous lightweight stone), adobe, tile and wood were used. Wood is an important decoration material especially in rooms. Houses were composed of $5-8$ rooms. Due to religion and customs, selamlik - harem distinction is observed in the houses of wealthy people.

\section{FORMATION OF ROOM IN TRADITIONAL TURKISH HOUSE and CHARACTERISTICS OF ROOM IN SAFRANBOLU HOUSES}

In the traditional Turkish house, each room is designed multi functionally to enable the shelter of an immediate family just like in a tent. Every activity such as cooking, eating, sitting, sleeping, having bath is carried out in the room (Fig. 5). However according to the assertation of Rheidt (1996, p.230); main room of the houses in Byzantine civilization which is one of the important civilizations of Anatolia is multi functional. Generally living, sleeping and domestic affairs were carried out in a single room. Therefore it is possible to say that Byzantine culture is also effective in the formation of the room of traditional Turkish house. Another view upon this subject is that divan which is shaped according to the sitting style of Turk is made with the effect of furniture called "kerevet" which is used by Byzantines (Tanyeli, 1996, p.96).

Either a house of little town, a city or a palace; planning of the rooms and types, features of the furniture had never changed. Because according to the living culture of Turks who migrated to Anatolia and accepted Islam religion; principles of simplicity, plainness and modesty are the essentials in the design of room (Fig. $6)$. 


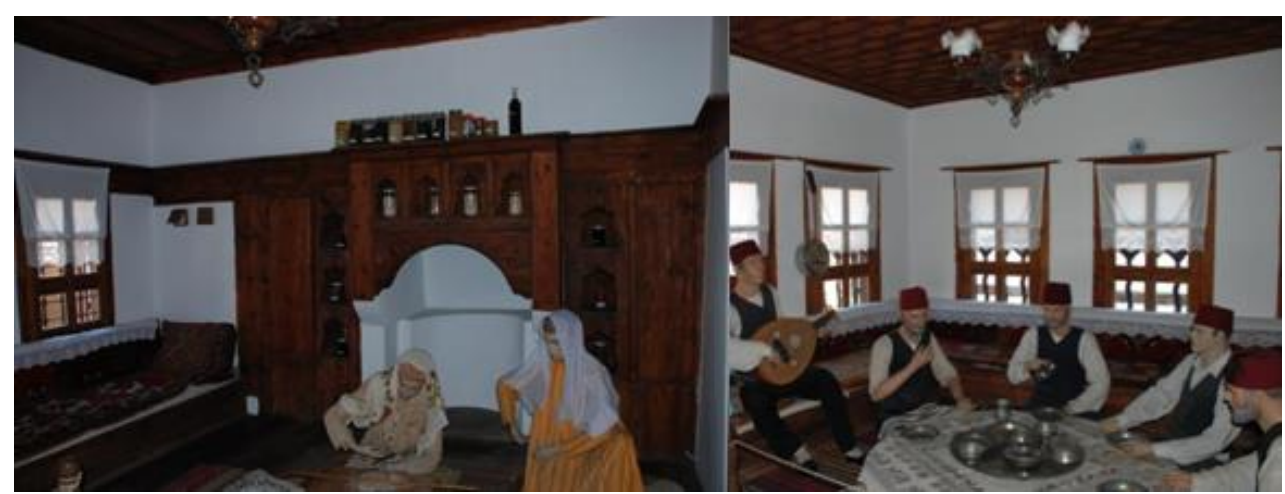

Figure 5: Multi functional usage of room in Traditional Turkish House - Safranbolu Kaymakamlar House.

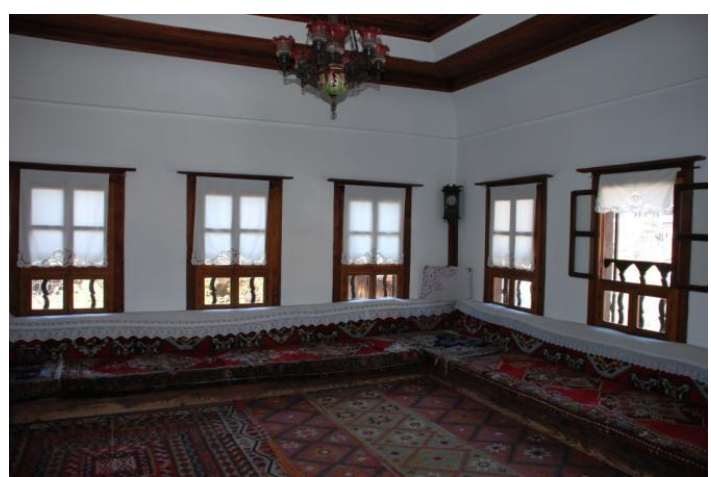

Figure 6: Basoda (main room) and interior design in Traditional Turkish House- Safranbolu Kaymakamlar House.
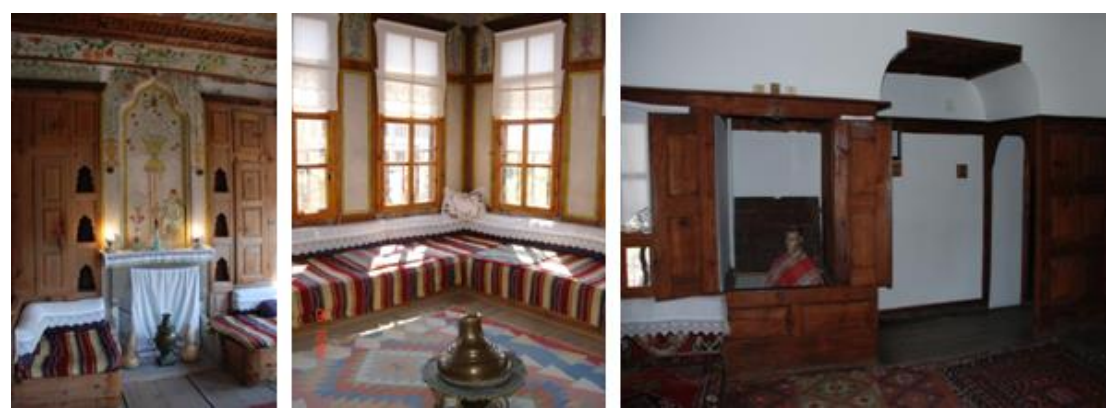

Figure 8: Usage of window, closets and built-in furniture in the upper part of the useful area - Safranbolu Yorukkoyu Sipahioğlu Residence (left and center picture). Special closet done for bathing in the roomSipahioğlu Kaymakamlar House (Right picture). 
However, the economic power of the user and his status in society was expressed with the interior design. Other than decoration techniques; every room carries the same features in the sense of planning. Flexibility is the main aim in order to provide multi functionality in the design. Flexibility of the place was provided by the equipments and belongings. Generally according to the size of timber; sitting, storage units and hearth are placed on walls in the square rooms of 3-4 $\mathrm{m}$. width. In this way the centre of the room is left empty in order to do various activities (Fig. 7). Functions are separated from each other with the sections. The room of the house where the guest are welcomed and which belongs to the householder is named as "basoda". Segmentation according to functions is clearly observed in basoda and is expressed with decoration. Just like in tent; living environment was formed portable in the room which is shaped with the principle of "earth is below us, firmament is above our head". Apart from respect towards nature, the characteristics of beauty, uniqueness and continuity are observed in the room (Kuban, 1995, p.96). For this reason the floor, ceiling and walls of the room are specially designed in the room. The ceiling of the room is not portable as it is in the tent. However, with decoration characteristics ceiling of "Yurt" was addressed. Since it is an element of structure that detects the status of room owner, decoration is minded with importance. It was resembled to tent decorations with geometrical motives done with special decoration techniques. Since most of the activities are carried out sedentarily, the floor is covered with matting or carpet. In order to provide hygienic conditions, floor of the room is separated from the floor of room entrance with rise. No one can enter the room with shoes. Walls are important in the formation of room. Walls are completely designed with the aim of functionality. One of the room walls are designed for storage and bathing unit, the other is for hearth and its surrounding, the rest are for sitting and windows. According to these activities and human sizes; walls are separated into three sections being "useful area, upper side of the useful area and rarely used area". This segmentation is ergonomic as Le Corbusier asserted and suits to Modular measures (Fig. 7). For example; the height of divan is $35-45 \mathrm{~cm}$. upper level of this useful area is $220 \mathrm{~cm}$. Useful area is simple and there is not much decoration. Few belongings were used in the room due to the principle of nomadic and TurkishIslamic living; "few but the main". Considering in this sense, there are similarities between traditional Turkish house and Japanese house. Portable belongings and fixed elements are organized in the useful area. Sitting unit divan, hearth, bathing unit are the most important components of this section. Shelves, windows, closets and built-in furniture are placed in the upper part of the useful area, belongings which must be rarely stored and upper windows are placed in the rarely used area (Fig. 8). Windows in this section were built in order to give light to the room just like the hole on the top of "Yurt". However they are not observed in every house. Bathing unit was placed in a closet in the upper part of useful area and it was named as "gusulhane" (Fig. 8). In order to provide the principle of privacy, entrances to the room was disconnected with a separating unit.

\section{FINDINGS: SIMILARITIES AND DIFFERENCES BETWEEN TENT AND ROOM FORMATION}

Although there is a similarity between room and tent in the sense of life style, when we consider etymologically the meaning of "house" in Pure Turkish is tent. ${ }^{38}$ It draws attention that the word "room" in Turkish ("oda") derives from the word "otağ (tent)" (Tanyeli, 1996, 427). Moreover, the existence of a village called "Yorukkoyu" in Safranbolu which takes its name from the nomadic Turks called "Yoruk" tells us that there is a connection between the shelters of nomadic period and room of traditional Turkish house. This village is proclaimed as a protected area and put under protection due to many traditional Turkish houses it holds. As it can be understood from here, it is possible to find the traces of nomadic life in traditional Turkish life and culture. As a result of the observation of findings; it is seen that daily life activities are carried out in the middle of the room in the places shaped by the needs of nomadic life and Turk-Islam life style. It is detected that activities are carried out in all the places considering the way of sitting and sitting area is designed specially, storage is placed at the edges of place so the centre is left empty for flexible usage. In the light of these data, it is detected that there is a relationship among the design criteria that enables the formation of room of tent and traditional Turkish house in the sense of aim, formation, shape, flexibility, living principles, privacy, belongings and furniture usage, hearth, sitting style, material and decoration, illumination and air conditioning. As a result of observations, it is detected that there are similarities and differences between the formation and usage style of tent and room.

Similarities between traditional Turkish house and tent in the sense of design criteria are:

- Aim: Tent and room are accepted as the centre of daily life and thought as a social life unit.

- Family Structure: There is only one immediate family in every tent and room. Connection of tents and rooms forms a shelter for bigger families.

- Flexibility: Flexible space is created with the structure and usage of belongings in tent and room.

- Living Principles: Simplicity and plainness is essential in the design of space in tent and room. Humility, 
modesty and respect towards nature are the most important design principles of these shelter units.

- Privacy: Privacy is regarded as a statement of respect in both of the shelter units. There is no permanent distinction in tent according to gender.

- Usage of belongings and furniture: Daily activities are carried out with portable belongings in room and tent. Storage function is places on the edges of the places. There is no furniture in western style.

- Hearth: Hearth is the centre of daily life. It is the focus point of the places.

- Sitting Style: "Turkish" sitting style is observed. Sitting activity is carried out in a section separated from the floor of the room. Other actions are shaped according to sitting style and the ergonomics of the space is formed.

- Material and Decoration: Prudence, easily accessing, easily forming and simplicity principles are regarded in the usage of space. Decoration is regarded as a hierarchical element of design which expresses the status of user in the society.

Differences between traditional Turkish house and tent in the sense of design criteria are:

- Formation: Formation of the space of tent is mobile, temporary. Formation of room is fixed and permanent. For the temporality of life principle; flexible solutions were used in the room.

- Shape: While the shape of Yurt is circular, the shape of Karacadır is rectangular; the shape of room is nearly square. However, the shape of place did not change the functions carried out in it.

- Illumination and Air-conditioning: There is no window in the tent. Illumination and air-conditioning is provided by the hole in the Yurt. Window was done for illumination and air-conditioning in the room. Rhythm is provided by the window in the design of place.

- Relationship among places: Relationship among tents is provided with usage of outer place as garden. Rooms are connected to each other with "sofa".

- Privacy: Privacy was regarded as a living style in Turkish houses. Sections of women and men are separated in a house. The room which is separated for the householder and hosting the guests was design separately. Although the entrance in the tent is direct, there is a separator between the entrance and room in the sense of privacy.

- Usage of belongings and furniture: Furniture is shaped together with structure in the room and is fixed. Western style furniture started to be used in the room of Turkish house from $19^{\text {th }}$ century onwards.

- Hearth: Hearth is placed in the middle of the place or close to the entrance in tent and has a separative function. Hearth is placed in the wall and the room is shaped according to the hearth.

- Sitting style: From the second half of $19^{\text {th }}$ century, with the effect of westernization and usage of Western style furniture in room, the way of sitting and other activities changed. This change caused change in the shape of room as well.

- Material and Decoration: While certain materials were used in the tent, structure materials differ according to climate and geographical region in the formation of Turkish house.

\section{RESULT}

Architectural heritage, life styles and traditions are the important components of culture and cultural identity. In this sense, residence can be defined as the transportation and interaction of cultural elements such as values, behaviours, abilities, information, traditions and habits for culture to culture or from person to person. Throughout history, Turkish house has been shaped according to the social and cultural infrastructure of the period and region due to activities and cultural behaviours of its user. Although there are some differences in the samples observed, it is seen that the planning and usage features of the room which forms the nucleus of traditional Turkish house suits with the nomadic period shelters and the residence is formed by the connection of these rooms with sofa (Fig. 9). 


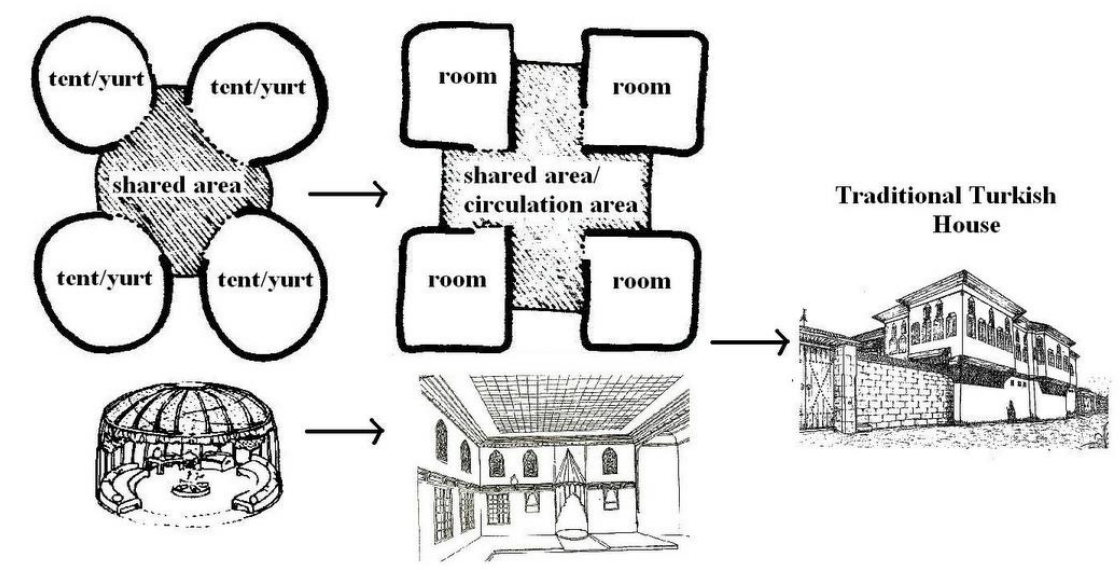

Figure 9: Transformation from tent to room and the formation of traditional Turkish house.

In the traditional Turkish house, room and its surrounding is shaped in an original principle in the sense of both size and shape and interior design. In the transformation form tent to traditional Turkish house; the place is regarded as three main activity areas developed according to sitting style in the sense of design criteria such as family structure, aim, flexibility, building principles, privacy, usage of belongings-furniture, hearth, sitting style, decoration and material and place platforms are formed by taking ergonomically measurements into regard. These components of design are same for palaces, mansions of rich people and the houses in rural regions. There are differences only in the decoration techniques and features of the rooms. Economical situation of the owner of a room and his status in the society is understood by the decoration of the room. Therefore decoration is the most important separation element in the design of a room. As the transformation from tent to room influences the development of traditional Turkish house, in some cases it influences European culture as well. It is seen that; traditional Turkish house is an original solution which develops according to the principles of nomadic period and Turk-Islam life styles, interacts with West in the period and environment in which it is built and has symbolic values.

\section{REFERENCE LIST}

Aksoy, E. (1963). "Middle Space, Basic Formation Principle in Turkish Civil Architecture”, Architecture and Art. No. 7-8: 39-92.

Arseven, C., E. (1955). History Of Turkish Art. İstanbul.

Çağatay, E.,Kuban, D. (2007). Speaking Turkish. Istanbul: Tetragon A.Ş.

Esin, E.(1981). Turkish Dome, From Seljuks to Gokturks . Ankara: Güven Matbaası.

Eldem, S. H. (1973). A Survey Of Turkish Kiosks And Pavilions. İstanbul: DGSA.

Eldem, S.H. (1984).Turkish House Ottoman Period VI. Istanbul: Türkiye Anıt, Çevre, Turizm değerlerini Koruma Vakfı.

Feilberg, C.,(1944). La Tente Noire: Contribution Etnographique A L'historie Culture İle Des Nomades.

Giray, K.(2002). “ Safranbolu - A Historical City.” Ilgi. No.104 (2002): 8-12.

Goker, M. (2009). "Historical Deveopment Process of Sitting Components at the Turks." ZfWT. Vol.1, No.1 (2009): 163.

Günay, R. (1999). Turkish House Tradition and Safranbolu Houses. Istanbul: Yem Yayınları.

Gur, Ş. O. (2002). Culture of House in Eastern Blacksea Sample. Istanbul: Yem Publishing.

Kademoğlu, O.(1974). "Three masted Tent among Yoruks." Mimarlık: 5 (1974): 29.

Koprulu, F., Gluck, H., Stryzgowski, J. (1974).Ancient Turkish Culture And Its Effects On Europe. Ankara:

Türk Tarih Kurumu Basımevi.

Kuban, D. (1995). Turkish Life House. Istanbul: Mısırlı Matbaacılık.

Kuban, D.(2001). Wooden Palaces. Istanbul: Yem Publishing. 
Kuban, D.(2007). Ottoman Architecture. Istanbul: Yem Publishing.

Kuçukerman, O.(1973). The rooms. Istanbul: Turkey touring and automobile Institution.

Larszle, R.(1981). Turk in History. Ankara: Türk Kültürünü Araştırma Enstitüsü Yayını, no:39.

Nute, K.(2000). Frank Lloyd Wright and Japan, Oxford: Alden Pres.

Norberg- Schulz, C. (1965). Intensions in Architecture. Cambridge: Mass. M.I. T Pres.

Onuk, T.(2005). Ottoman Tent Art. Ankara: Atatürk Kültür Merkezi Başkanlığı Yayınları..

Ozguven, B.. "The Ottoman House". Edited by Stanley Ireland, William Bechhoefer, Papers From The Amasya Symposium, 24-27 september 1996, British Institute of Archelology at Ankara, p.16-20.

Ozkan, S.(1974). " Dynamism in Architecture and Alaçik.", Mimarlık:5 (1974): 22.

Rapoport, A.(1982). The Meaning Of The Built Environment: A Non- Verbal Communication Approach. Beverly hills CA: Sage.

Rheidt, K.(1996). Housing and settlement pattern in Byzantine, Pre-Ottoman and Otoman periods in Anatolia. Housing And Settlement In Anatolia: A Historical Perspective. Edited by Yıldız Sey. Istanbul: Türkiye Tarih Vakfı.,1999, p.230.

Şahin, I. (2003). " Safranbolu in Turkish Settlement Process in Anatolia.", I. Symposium of Safranbolu in National History, Ankara: Turkish History Institution.

Sheets- Johnstone, M. (1994). The Roots Of Power, Animate Form And Gendered Bodies. Illinois: Open Court Publishing Company.

Tanyeli, U.(1978). Evolution Process of Physical Structure in Anatolian Turkish City (XI-XV Centuries). İstanbul: İstanbul Technical University Pres.

Tanyeli, U. (1996).. Housing and Settlement pattern in Byzantine, Pre-Ottoman and Ottoman periods in Anatolia. Housing And Settlement In Anatolia: A Historical Perspective. Edited by Yıldız Sey. Istanbul: Türkiye Tarih Vakfı.p., 405-471.

Yurekli, H.,Yurekli, F.(2005). The Turkish House. İstanbul: Yapı Endüstri Merkezi Yayınları.

Wright, G.R. H. (1958). “Tents and Domes in Persia.”, Man 58 (1958): 159-160. 